\title{
Double serum sampled glomerular filtration rate measurement with technetium-99m diethylenetriamine-penta acetate for evaluation of renal functions in patients with psoriasis vulgaris
}

Psoriazis vulgaris hastalarında böbrek fonksiyonlarının değerlendirilmesi için technetium 99m-dietilentriamin-penta asetat ile çift serum örnekli glomerüler filtrasyon hızı ölçümü

๑ Rukiye Yasak Güner, ๑ Sibel Berksoy Hayta*, ๑ Melih Akyol, ๑ Zekiye Hasbek**,
๑ Sedat Özçelik, ๑ Meryem Timuçin***

Sivas Cumhuriyet University Faculty of Medicine, Department of Dermatology, Sivas, Turkey

*Acıbadem Medical Group, Department of Dermatology, İstanbul, Turkey

**Sivas Cumhuriyet University Faculty of Medicine, Department of Nucleer Medicine, Sivas, Turkey

***Amasya University Sabuncuoğlu Șerefeddin Training and Research Hospital, Clinic of Nephrology, Amasya, Turkey

\begin{abstract}
Background and Design: Psoriasis is a common chronic inflammatory skin disease believed to affect renal functions. Glomerular filtration rate (GFR) is the most important indicator used to assess renal functions. The present study aims to measure the renal function of psoriasis patients via the technetium-99m diethylenetriamine pentaacetate (Tc-99m DTPA) method and compare the values obtained with those determined through indirect measurement methods, such as the modification of diet in renal disease (MDRD) and chronic kidney disease epidemiology collaboration (CKD-EPI), considering the effects of systemic treatments and comorbidities.

Materials and Methods: Eighty-seven patients diagnosed with chronic plaque-type psoriasis vulgaris were included in this study. The patients' demographic characteristics, disease duration, psoriasis area and severity index score, drugs received for psoriasis treatment, comorbidities, and drugs received for comorbidity treatment were noted. Estimated GFRs were also calculated using the MDRD and CKD-EPI formulas.

Results: Tc-99m DTPA values were affected only by age. As the patient age increased, a significant decrease in GFR measured with Tc-99m DTPA $(r=0.289, p<0.001)$ was observed.

Conclusion: Psoriasis, comorbidities, and nephrotoxic drugs used for treatment did not affect renal functions. GFR measurements were affected only by age.

Keywords: CKD-EPI, MDRD, psoriasis, renal functions, Tc-99m DTPA GFR

Öz

Amaç: Psoriazis yaygın, kronik ve enflamatuvar bir deri hastalığıdır. Birçok çalışmada psoriazisin böbrek fonksiyonlarını etkilediği bildirilmiştir. Glomerüler filtrasyon hızı (GFR) böbrek fonksiyonlarının değerlendirilmesinde kullanılan en önemli göstergedir. Bu çalışma; psoriazise eşlik eden komorbitideler ve tedaviler göz önüne alınarak, dermatoloji polikliniğine gelen psoriazis hastalarının böbrek fonksiyonlarının technetium-
\end{abstract}

Address for Correspondence/Yazışma Adresi: Rukiye Yasak Güner MD, Sivas Cumhuriyet University Faculty of Medicine, Department of Dermatology, Sivas, Turkey Phone: +90 3462581200 E-mail: rky.guner@gmail.com Received/Geliş Tarihi: 24.02.2020 Accepted/Kabul Tarihi: 27.01.2021 ORCID: orcid.org/0000-0002-5154-4652

Cite this article as: Yasak Güner R, Berksoy Hayta S, Akyol M, Hasbek Z, Özçelik S, Timuçin M. Double serum sampled glomerular filtration rate measurement with technetium $99 \mathrm{~m}$-diethylenetriamine-penta acetate for evaluation of renal functions in patients with psoriasis vulgaris. Turkderm-Turk Arch Dermatol Venereol 2021;55:108-12

C Copyright 2021 by Turkish Society of Dermatology and Venereology

Turkderm - Turkish Archives of Dermatology and Venereology published by Galenos Yayınevi. 
99m diethylenetriamine pentaacetate (Tc-99m DTPA) ile değerlendirmeyi ve böbrek hastalıklarında diyet değişikliği denklemi (MDRD) ve kronik böbrek hastalığı epidemiyolojisi iş birliği denklemi (CKD-EPi) gibi indirekt ölçüm yöntemleri ile karşılaştırmayı amaçlamaktadır.

Gereç ve Yöntem: Çalışmaya kronik plak tip psoriazis vulgaris tanısı olan 87 hasta alındı. Hastaların demografik özellikleri, hastalık süresi, psoriazis alan şiddeti indeksi skoru, şu ana kadar psoriazis için kullanmış olduğu ilaçlar, ek hastalıklar, ek hastalıklar için kullanmakta olduğu ilaçlar not edildi. Tahmini GFR, Tc-99m DTPA ile GFR ölçümü yapılan hastalarda MDRD ve CKD-EPI formülleri ile hesaplanmıştır.

Bulgular: Tc-99m DTPA değeri sadece yaştan etkilenmiştir. Yaş arttıkça, Tc-99m DTPA ile ölçülen GFR'de anlamlı bir azalma gözlendi ( $r=0,289$, $p<0,001)$.

Sonuç: Bu çalışmada, psoriazisin ve tedavi amaçlı kullanılan nefrotoksik ilaçların böbrek fonksiyonlarını etkilemediğini bulduk. GFR değeri sadece yaştan etkilenmiştir. Anahtar Kelimeler: CKD-EPI, MDRD, psoriazis, böbrek fonksiyonları, Tc-99m DTPA GFR

\section{Introduction}

Psoriasis is a common chronic inflammatory skin disease with a prevalence of $2 \%-3 \%$. The disease is generally considered a systemic inflammatory disorder associated with various comorbidities, such as metabolic syndrome, cardiovascular disease, psychological/psychiatric disorders, inflammatory intestinal disease, and insulin resistance ${ }^{1,2}$. Psoriasis causes a complex immunological reaction resulting in abnormal keratinocyte differentiation ${ }^{3}$. The pathogenesis of comorbidity in psoriasis patients is yet unknown, but common inflammatory pathways, cellular mediators, genetic predisposition and common risk factors are contributing factors ${ }^{2}$. Recent studies have revealed that psoriasis is a risk factor for chronic kidney disease (CKD), including end-stage CKD, independent from other risk factors such as diabetes, cardiovascular disease, and hypertension. It is considered to be caused by several conditions, including immune-mediated renal damage, drug-induced renal damage, and chronic renal damage ${ }^{47}$. However, in contrast to these studies, other researchers have demonstrated no relationship between psoriasis and renal abnormalities ${ }^{8-10}$.

Glomerular filtration rate (GFR) is the most important indicator used to assess renal function. Insulin clearance is accepted as the gold standard of GFR measurement, but it is inconvenient and expensive. These limitations have motivated other clinicians to use alternative methods for measuring GFR instead"1. The modification of diet in renal disease (MDRD), chronic kidney disease epidemiology collaboration (CKD-EPI), and Cockroft-Gault (C\&G) methods measure GFR by calculating the level of serum creatinine and are used throughout the world. However, while these formulas are known to show low error and high accuracy in patients with GFR $<60 \mathrm{~mL} / \mathrm{min}$, they do not provide accurate information of GFR in periods during which renal functions change rapidly ${ }^{12,13}$.

MDRD, KCD-EPI, and C\&G are often employed to calculate GFR values because they are easy to use, but double serum-sampled GFR with technetium-99m diethylenetriamine pentaacetate (Tc-99m DTPA) is still considered the gold standard throughout the world. Tc-99m DTPA provides accurate results even in the case of reduced clearance levels, such as $10 \mathrm{~mL} / \mathrm{min}$. Previous studies assessed psoriasis by examining kidney involvement, blood creatine level, GFR measurements (MDRD, C\&G, CKD-EPI), and urinary albumin levels ${ }^{47}$. However, these serum parameters show remarkable changes only when the GFR decreases by approximately $50 \%$; in other words, changes to these parameters are detected only after renal damage occurs. The present study aims to measure the renal functions of psoriasis patients measured with double serum-sampled Tc-99m DTPA and compare the results obtained with those determined through indirect measurement methods, such as MDRD and CKD-EPI, considering the effects of systemic treatments and comorbidities.

\section{Materials and Methods}

Approval was obtained from the Clinical Trial Ethics Committee of the Medical Faculty Hospital of Cumhuriyet University (approval number: 2017-01/25, date: 17.01.2017). Informed consent was obtained. Eighty-seven patients diagnosed with chronic plaque-type psoriasis vulgaris and receiving treatment at a dermatology outpatient clinic were included in the study. The demographic characteristics, disease duration, psoriasis area and severity index (PASI) score, nail psoriasis severity index, drugs used for psoriasis treatment, comorbidities (e.g., hypertension, diabetes mellitus, and cardiovascular disease), and drugs used for comorbidity treatment were noted. Patients under the age of 18 and those who were pregnant were excluded from the study. No healthy volunteer group was included in this work. Physical (e.g., height, weight, and body mass index) and biochemical (e.g., urea, creatinine, albumin, sodium, potassium, chlorine, magnesium, bicarbonate, and complete urine test) parameters used in routine follow-up were recorded.

Psoriasis with a PASI score of $\leq 10$ was assessed as mild while that with a score of $>10$ was assessed as moderate-severe. The ages of the patients were grouped as above and below 45 years on the basis of the median value of the group. Disease duration was grouped as 0-10 years, $11-20$ years, and $>21$ years. GFR $\leq 90 \mathrm{~mL} / \mathrm{min} / 1.73 \mathrm{~m}^{2}$ was considered decompensated, whereas GFR $>90 \mathrm{~mL} / \mathrm{min} / 1.73^{2}$ was considered normal.

\section{GFR measurement}

Estimated GFRs were also calculated using the MDRD and CKD-EPI formulas. During these calculations, all of the patients were considered to be of Caucasian race.

\section{Tc-99m DTPA GFR}

Plasma clearance of Tc-99m labeled DTPA was measured to assess GFR by using two blood samples and the slope-intercept method. Tc99m DTPA was prepared from fresh pertechnetate and a DTPA kit (Pentacis ${ }^{\circledR}$, CIS Bio International, France). The Tc-99m DTPA labeling efficiency was $>98 \%$. After intravenous administration of DTPA (37 MBq), blood samples $(5 \mathrm{~mL})$ were collected at 2 and $4 \mathrm{~h}$ into heparinized syringes. The plasma was separated, and radioactivity was assayed in a well-type gamma counter (Berthold, Germany). Absolute GFRs were then obtained using the following equation.

Clearance (Tc-99m DTPA) $=\mathrm{D} \times \ln (\mathrm{P} 1 / \mathrm{P} 2) / \mathrm{T} 2-\mathrm{T} 1 \times \exp (\mathrm{T} 1 \mathrm{ln} \mathrm{P} 2)-(\mathrm{T} 2 \mathrm{ln}$ P1)/T2-T1.

Where $\mathrm{D}=$ =injected dose (counts/min), P1=plasma activity at $\mathrm{T} 1$ (counts/ $\mathrm{min} / \mathrm{mL}$ ), and P2=plasma activity at T2 (counts/min/mL).

The values obtained were normalized to the body surface area and corrected via the Brochner-Mortensen method. 


\section{MDRD calculation:}

$\mathrm{GFR}=175 \times[($ serum creatinine-1.154) $\times[($ age- -0.203$) \times(0.742$ if the person is female)].

\section{CKD-EPI calculation:}

$\mathrm{GFR}=141 \times \min (\mathrm{Scr} / \kappa, 1) \alpha \times \operatorname{maximum}(\mathrm{Scr} / \kappa, 1)-1.209 \times 0.993$ age $\times 1.018$ (if the person is female) where $\mathrm{Scr}=$ serum creatinine $(\mathrm{mg} / \mathrm{dL})$, $\kappa=0.7$ for females and 0.9 for males, and $\alpha=-0.329$ for females and -0.411 for males).

\section{Statistical Analysis}

Logistic regression was used to analyze the factors affecting Tc99m DTPA GFR. Gender, age, disease duration, PASI score $(<10$, mild psoriasis; >10 moderate-severe psoriasis), nail involvement, administered drugs, and presence of comorbidities were used as independent parameters for logistic regression. Bland-Altman analysis was used to compare whether the results of Tc-99m DTPA GFR, MDRD, and CKD-EPI could substitute for each other. A p-value of $<0.05$ was accepted as statistically significant.

\section{Results}

Eighty-seven psoriasis patients (44 males, 43 females) were included in the study. The average age of the patients was $45.8 \pm 13.9$ for males and $40.6 \pm 15.1$ for females. According to the PASI scores obtained, $60(68.9 \%)$ of the patients had mild psoriasis while $27(31 \%)$ had moderate-severe psoriasis. Twenty-seven (31\%) of the patients did not have a comorbidity, while 60 (68.9\%) had a comorbidity. Sixteen (18.3\%) patients used topical treatment, whereas 71 (81.5\%) used systemic (e.g., methotrexate, cyclosporine, acitretin, and/or biological agent) drugs. Among the patients included in our study, 16 (18.3\%) actively used only topical treatments, 25 (28.7\%) used methotrexate, 1 (1.1\%) used cyclosporine, 5 (5.7\%) used acitretin, and $22(25.2 \%)$ used biological agents. A total of 14 (16\%) patients had not received prior treatment for psoriasis. The number of patients who had used methotrexate at least once for psoriasis treatment was 37 (69.8\%), while the number of patients who had used cyclosporine at least once was $8(15 \%)$. The drug use options of the patients were divided into two groups of topical and systemic drugs for statistical analysis.

Independent variables that were significant in all tables were marked (Table 1), and the analysis was repeated by removing meaningless variables from the model. The results are given in the Table 2 . According to the results of logistic regression analysis, only age affected GFR values measured with Tc-99m DTPA. Specifically, as the patient age increased, GFR measured with Tc-99m DTPA statistically significantly decreased $(r=0.289, p<0.00$; Table 2).

MDRD and CKD-EPI values were also measured in the patient group. The correlations among the three measurement methods were statistically assessed by using Bland-Altman analysis. Tc-99m DTPA GFR and MDRD could not substitute for each other after it was determined that the model was not significant as a result of the type 2 regression. While previous researchers believed that Tc-99m DTPA GFR, CKD-EPI and MDRD-CKD-EPI measurements may substitute for each other, the $R^{2}$ values obtained in both models was low (Table 3 ). These results reveal that CKD-EPI and MDRD measurements in the patient group do not directly reflect Tc-99m DTPA GFR measurement results (Figure 1).

\begin{tabular}{|c|c|c|c|c|c|c|}
\hline $\begin{array}{l}\text { Independent } \\
\text { variables }\end{array}$ & B & S.E. & Wald & df & Sig. & Exp ( \\
\hline Gender & 0.142 & 0.760 & 0.035 & 1 & 0.852 & 1.153 \\
\hline Age & 5.341 & 1.698 & 9.895 & 1 & 0.002 & 208.66 \\
\hline $\begin{array}{l}\text { Disease } \\
\text { duration }\end{array}$ & -0.045 & 0.040 & 1.249 & 1 & 0.264 & 0.956 \\
\hline PASI & 1.844 & 1.053 & 3.067 & 1 & 0.080 & 6.323 \\
\hline $\begin{array}{l}\text { Nail } \\
\text { involvement }\end{array}$ & -0.068 & 0.051 & 1.804 & 1 & 0.179 & 0.934 \\
\hline $\begin{array}{l}\text { Administered } \\
\text { drugs }\end{array}$ & 0.003 & 0.033 & 0.011 & 1 & 0.918 & 1.003 \\
\hline Comorbidities & -0.131 & 0.964 & 0.019 & 1 & 0.892 & 0.877 \\
\hline Constant & -0.100 & 0.031 & 10.089 & 1 & 0.001 & 0.905 \\
\hline
\end{tabular}

MDRD's logistic regression variables in the equation table

\begin{tabular}{|l|l|l|l|l|l|l|}
\hline Gender & -0.045 & 0.650 & 0.005 & 1 & 0.945 & 0.956 \\
\hline Age & 2.958 & 1.294 & 5.226 & 1 & $\mathbf{0 . 0 2 2}$ & 19.264 \\
\hline $\begin{array}{l}\text { Disease } \\
\text { duration }\end{array}$ & 0.018 & 0.030 & 0.339 & 1 & 0.560 & 1.018 \\
\hline PASI & 0.327 & 0.771 & 0.180 & 1 & 0.671 & 1.387 \\
\hline $\begin{array}{l}\text { Nail } \\
\text { involvement }\end{array}$ & -0.055 & 0.043 & 1.663 & 1 & 0.197 & 0.946 \\
\hline $\begin{array}{l}\text { Administered } \\
\text { drugs }\end{array}$ & 0.005 & 0.027 & 0.035 & 1 & 0.852 & 1.005 \\
\hline Comorbidities & 0.495 & 0.827 & 0.358 & 1 & 0.549 & 1.640 \\
\hline Constant & -0.059 & 0.025 & 5.521 & 1 & $\mathbf{0 . 0 1 9}$ & 0.943 \\
\hline CKD-EPI's logistic regression
\end{tabular}

CKD-EPI's logistic regression variables in the equation table

\begin{tabular}{|c|c|c|c|c|c|c|}
\hline Gender & -0.356 & 0.799 & 0.199 & 1 & 0.656 & 0.700 \\
\hline Age & -0.020 & 0.029 & 0.477 & 1 & 0.490 & 0.980 \\
\hline $\begin{array}{l}\text { Disease } \\
\text { duration }\end{array}$ & 0.004 & 0.034 & 0.012 & 1 & 0.912 & 1.004 \\
\hline PASI & 0.640 & 0.988 & 0.420 & 1 & 0.517 & 1.897 \\
\hline $\begin{array}{l}\text { Nail } \\
\text { involvement }\end{array}$ & -0.013 & 0.054 & 0.059 & 1 & 0.808 & 0.987 \\
\hline $\begin{array}{l}\text { Administered } \\
\text { drugs }\end{array}$ & 0.016 & 0.035 & 0.218 & 1 & 0.641 & 1.016 \\
\hline Comorbidities & -0.463 & 0.949 & 0.238 & 1 & 0.626 & 0.630 \\
\hline Constant & 2.811 & 1.538 & 3.338 & 1 & 0.038 & 16.618 \\
\hline \multicolumn{7}{|c|}{$\begin{array}{l}\text { nGFR: Glomerular filtration rate, PASI: Psoriasis area and severity } \\
\text { index, MDRD: Modification of diet in renal disease, CKD-EPI: Chronic } \\
\text { kidney disease epidemiology collaboration }\end{array}$} \\
\hline
\end{tabular}

\section{Discussion}

The aim of the present study is to compare double serum-sampled Tc99m DTPA, MDRD, and CKD-EPI values to assess the effect of psoriasis, its comorbidities, and nephrotoxic drugs used for treatment on renal function. The results indicated that CKD-EPI and MDRD measurements cannot directly reflect Tc-99m DTPA GFR measurements. Thus, the latter may be a more accurate method for assessing renal functions compared with the former. 
Table 2. Results of age-related logistic regression analysis

\begin{tabular}{|c|c|c|c|c|c|c|}
\hline \multirow{2}{*}{ Dependent variable } & \multirow{2}{*}{ Independent variable } & \multirow{2}{*}{ Cox \& snell R2 } & \multirow{2}{*}{ Nagelkerke R2 } & \multirow{2}{*}{ B } & \multicolumn{2}{|l|}{ p-value } \\
\hline & & & & & Coefficient & Model \\
\hline Tc-99m DTPA & Fixed & 0.289 & 0.392 & -0.103 & $<0.001$ & $<0.001$ \\
\hline \multirow{2}{*}{ MDRD } & Fixed & \multirow{2}{*}{0.094} & \multirow{2}{*}{0.128} & -0.048 & 0.008 & \multirow{2}{*}{0.043} \\
\hline & Age & & & 2.637 & 0.022 & \\
\hline
\end{tabular}

Table 3. Comparison of different measurement methods via a type 2 regression model

\begin{tabular}{|l|l|l|l|l|}
\hline Type 2 regression & Fixed & B & $\mathbf{R}^{\mathbf{2}}$ & $\mathbf{p}$ \\
\hline GFR-MDRD & -0.905 & 0.011 & 0.012 & 0.938 \\
\hline GFR-CKD-EPI & $-44,425$ & 0.400 & 0.104 & $\mathbf{0 . 0 0 1}$ \\
\hline MDRD-CKD-EPI & $-36,057$ & 0.317 & 0.257 & $<\mathbf{0 . 0 0 1}$ \\
\hline
\end{tabular}

GFR: Glomerular filtration rate, MDRD: Modification of diet in renal disease, CKD-EPI: Chronic kidney disease epidemiology collaboration
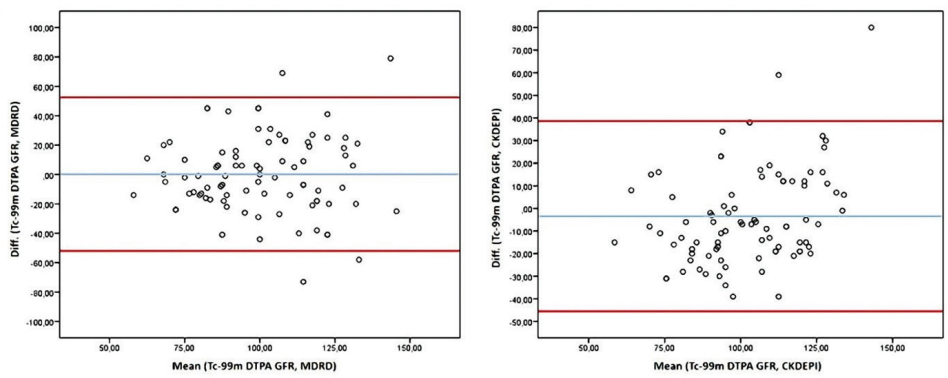

Figure 1. Comparison of different measurement methods via BlandAltman analysis

GFR: Glomerular filtration rate, Tc-99m DTPA: Technetium-99m diethylenetriamine pentaacetate, MDRD: Modification of diet in renal disease, CKD-EPI: Chronic kidney disease epidemiology collaboration

The present study also indicated that psoriasis duration, its comorbidities, nephrotoxic drugs used for treatment, PASI scores, and nail involvement do not affect renal dysfunctions based on this measurement method.

While the mechanisms through which psoriasis causes renal damage remain unclear, some researchers have proposed metabolic and cardiovascular comorbidities or the use of nephrotoxic drugs as contributing factors ${ }^{47,14}$. Most previous studies reported that renal dysfunction has developed are retrospective and have used MDRD, C\&G and CKD-EPI for renal assessment. When the English literature was reviewed, no study assessing renal functions with Tc-99m DTPA in psoriasis patients was found. In the present study, GFR was assessed with Tc-99m DTPA, and no correlation between psoriasis duration, severity of psoriasis, comorbidity, or use of nephrotoxic drugs and renal dysfunction was found.

Serum creatinine level, age, gender, and ethnicity are used to assess renal functions with MDRD and CKD-EPI. However, because muscle produces creatinine, muscle mass may affect these values; the coefficients used for different ethnic communities may also affect GFR ${ }^{15-17}$. Previous studies indicated that these measurements have a limited role in assessments of renal function, especially in patients with (GFR >60 $\left.\mathrm{mL} / \mathrm{min} / 1.73 \mathrm{~m}^{2}\right)^{5,15,16}$. DRD, C\&G, and CKD-EPI are frequently used to calculate GFR because they are convenient in daily practice; however, double serum-sampled GFR with Tc-99m DTPA is used as the reference method throughout the world. Thus, measurement of GFR with TC99m DTPA appears to be a more appropriate method to assess renal function and serum creatinine level. Tc-99m DTPA provides accurate results even under reduced clearance levels, such as $10 \mathrm{~mL} / \mathrm{min}$. Unfortunately, because the test is time consuming and inconvenient, its use is limited ${ }^{18}$.

Although the presence of microalbuminuria in 24-hour urine, which is a symptom of subclinical glomerular dysfunction in psoriasis patients, was noted, no abnormality was determined in the microalbuminuria or albumin/creatinine levels determined in spot urine in the present study $^{9,19}$. Some studies have suggested that the level of albumin/ creatinine in spot urine is a reliable method; however, this may be accepted as a limitation of the present study ${ }^{20,21}$.

Patients receiving topical and systemic drugs were included in the study, and no renal dysfunction was determined in these groups. This finding may be attributed to the nature of the drugs to suppress inflammation, which exerts a nephroprotective effect. The decrease in GFR with increasing age in psoriasis patients may be associated with age-related glomerulus and glomerular capillary vessel loss, non-functionality of the vascular auto-regulatory system, and tubular fragility ${ }^{21-23}$.

\section{Study Limitations}

A limitation of the present study is that it did not include a healthy volunteer group.

\section{Conclusion}

Psoriasis, its comorbidities, and nephrotoxic drugs used for treatment did not affect renal functions. GFR measurement with Tc-99m DTPA is more reliable than indirect measurement methods for detecting suspected renal dysfunction in psoriasis patients.

Acknowledgments: We thank Mr. Selim Cam for his assistance with the statistical analysis.

\section{Ethics}

Ethics Committee Approval: Approval was obtained from the Clinical Trial Ethics Committee of the Medical Faculty Hospital of Cumhuriyet University (approval number: 2017-01/25, date: 17.01.2017).

Informed Consent: Informed consent was obtained.

Peer-review: Externally peer-reviewed. 


\section{Authorship Contributions}

Concept: R.Y.G., M.A., S.B.H., S.Ö., M.T., Design: R.Y.G., M.A., Data Collection or Processing: R.Y.G., M.A., S.B.H., S.Ö., M.T., Analysis or Interpretation: R.Y.G., M.A., Literature Search: Z.H., Writing: R.Y.G., M.A.

Conflict of Interest: The authors declare that they have no conflict of interest.

Financial Disclosure: This study was funded by Cumhuriyet University Scientific Research Projects Automation (grant no: T-790).

\section{References}

1. Akyol M, Alper $\mathrm{S}$, Atakan $\mathrm{N}$, et al: Turkish guideline for the treatment of psoriasis. Turkderm-Turk Arch Dermatol Venereol 2016;50:33-6.

2. Takeshita J, Grewal S, Langan SM, et al: Psoriasis and comorbid diseases part I. Epidemiology. J Am Acad Dermatol 2017;76:377-90.

3. Ogawa E, Sato Y, Minagawa A, Okuyama R: Pathogenesis of psoriasis and development of treatment. J Dermatol 2018;45:264-72.

4. Jabbar-Lopez ZK, Weatherhead SC, Reynolds NJ: Kidney disease in moderateto-severe psoriasis: a critical appraisal. Br J Dermatol 2016;174:267-70.

5. Wan J, Wang S, Haynes K, Denburg MR, Shin DB, Gelfand JM: Risk of moderate to advanced kidney disease in patients with psoriasis: population based cohort study. BMJ 2013;347:f5961.

6. Chi CC, Wang J, Chen YF, Wang SH, Chen FL, Tung TH: Risk of incident chronic kidney disease and end-stage renal disease in patients with psoriasis: a nationwide population-based cohort study. J Dermatol Sci 2015;78:232-8

7. Visconti L, Leonardi G, Buemi M, et al: Kidney disease and psoriasis: novel evidences beyond old concepts. Clin Rheumatol 2016;35:297-302.

8. Tehranchinia Z, Ghanei E, Mohammadi N, Partovi-Kia M, Rahimi H, Mozafari $\mathrm{N}$ : No Relation between psoriasis and renal abnormalities:a case-control study. ScientificWorldJournal 2018:2018:5301631.

9. Dervisoglu E, Akturk AS, Yildiz K, Kiran R, Yilmaz A: The spectrum of renal abnormalities in patients with psoriasis. Int Urol Nephrol 2012;44:509-14.
10. Kaftan O, Kaftan B, Toppare MF, Ekşioğlu M: Renal involvement in psoriasis. Dermatology 1996;192:189-90.

11. Soveri I, Berg UB, Björk J, et al: Measuring GFR: a systematic review. Am J Kidney Dis 2014;64:411-24.

12. Stevens LA, Coresh J, Feldman HI, et al: Evaluation of the modification of diet in renal disease study equation in a large diverse population. J Am Soc Nephrol 2007;18:2749-57.

13. Drenth-van Maanen $A C$, Jansen $P A$, Proost $J H$, et al: Renal function assessment in older adults. Br J Clin Pharmacol 2013;76:616-23.

14. Ungprasert P, Raksasuk S: Psoriasis and risk of incident chronic kidnet disease and end-stage renal disease:a systematic reviev and meta-analysis. Int Urol Nephrol 2018;50:1277-83.

15. Amin A, Effat D, Goher N, Ramadan B: LTc-99 m diethylenetriaminepentaacetic acid (DTPA): is it reliable for assessment of methotrexateinduced cumulative effect on renal filtration in rheumatoid arthritis patients? Rheumatol Int 2013;33:3059-63.

16. Lee CS, Cha RH, Lim YH, et al: Ethnic coefficients for glomerular filtration rate estimation by the Modification of Diet in Renal Disease study equations in the Korean population. J Korean Med Sci 2010;25:1616-25.

17. Stevens LA, Coresh J, Green T, Levey AS: Assessing kidney function-measured and estimated glomerular filtration rate. N Engl J Med 2006;354:2473-83.

18. Suebmee P, Foocharoen C, Mahakkanukrauh A, et al: Correlation of glomerular filtration rate between renal scan and estimation equation for patients with scleroderma. Am J Med Sci 2016;352:166-71.

19. Szepietowski JC, Bielicka E, Wasik F, Kopec W, Szepietowski T: Microalbuminuria as a subclinical marker of renal impairment in subjects with psoriasis vulgaris. J Eur Acad Dermatol Venereol 2000;14:513-4

20. Jones CA, Francis ME, Eberhardt MS, et al: Microalbuminuria in the US population:third national health and nutrition examination survey. Am J Kidney Dis 2002;39:445-59.

21. Raman M, Middleton RJ, Kalra PA, Green D: Estimating renal function in old people: an in-depth review. Int Urol Nephrol 2017;49:1979-88.

22. Denic A, Glassock RJ, Rule AD: Structural and functional changes with the aging kidney. Adv Chronic Kidney Dis 2016;23:19-28.

23. O'Sullivan ED, Hughes J, Ferenbach DA: Renal aging: causes and consequences. J Am Soc Nephrol 2017;28:407-20. 